\title{
Effects of Biological and Analytical Variations on the Appropriate Use of "Reference Intervals" in Clinical Chemistry. Proposal of a Scheme for Longitudinal Assessment of Laboratory Values
}

\author{
By G. M. P. J. Costongs, P. C.W. Janson
}

Department of Clinical Chemistry Hospital "De Goddelijke Voorzienigheid" Sittard, The Netherlands and

\section{P. J. Brombacher}

Department of Clinical Chemistry De Wever Hospital Heerlen, The Netherlands

(Received November 15, 1982/November 18, 1983/June 21, 1984)

Summary: For twenty one different laboratory parameters the separate contributions of both biological (age, sex, hospitalisation) and analytical variations to the total variation have been examined. For each of the different laboratory parameters the reference interval and critical difference are given for the longitudinal evaluation of analysis results.

These critical differences are not only calculated on the basis of the analytical imprecision from day to day, as has been usual until now, but the mean individual deviations of the reference samples have also been included. The critical differences given in this paper are therefore essentially higher for some parameters compared with the critical differences on the basis of the analytical deviation, and are therefore much more realistic quantities to be used for longitudinal evaluation.

Finally for practical purposes a scheme is presented for use with longitudinal assessment of laboratory values, in order to enable the practising physician to consider these data in daily decision making.

Wirkungen biologischer und analytischer Varianzen auf den angemessenen Gebrauch von „Referenzintervallen" in der Klinischen Chemie.

Vorschlag eines Schemas zur longitudinalen Bewertung von Laboratoriumsergebnissen.

Zusammenfassung: Der separate Beitrag von biologischer (Alter, Geschlecht, Krankenhausaufenthalt) und analytischer Varianż zưr Gesamtvarianz wurde für 21 verschiedene Laboratoriumskenngrößen ermittelt. Für jede der verschiedenen Laboratoriumskenngrößen wird der Referenzbereich und die kritische Differenz für die longitudinale Bewertung der Analysenergebnisse angegeben.

Diese kritische Differenzen wurden niçht allein aufgrund der analytischen Impräzision von Tag zu Tag, wie bisher üblich, berechnet, sondern die mittleren individuellen Abweichungen der Referenzproben wurden einbezogen.

Die in diesem Beitrag angegebenen kritischen Differenzen sind deshalb, verglichen mit den kritischen Differenzen aufgrund der analytischen Abweichung, wesentlich größer; sie sind daher sehr viel realistischere Grössen für die Durchführung einer longitudinalen Bewertung. Für praktische Zwecke wird ein Schema zur Anwendung bei longitudinaler Bewertung von Laboratoriumsergebnissen angegeben, um dem praktizierenden Arzt die Berücksichtigung dieser Daten im täglichen Entscheidungsprozeß zu ermöglichen. 


\section{Introduction}

Results for the determination of concentrations of serum constituents are dependent on several analytical and biological factors. Recent developments in analytical laboratory techniques, such as introduction of automatic analysers, development of highly standardised techniques and highly sensitive detection reactions, etc., have considerably reduced the analytical bias. However, further study of biological factors influencing the laboratory data is necessary. Hitherto, results of laboratory investigations have usually been compared to reference intervals ("normal values") in order to determine normality or abnormality (transverse assessment), i.e. to discriminate between health and disease.

Reference values and inter-individual variations are determined from samples from an apparently healthy population, often a selected group of the total population. Means and standard deviations are calculated and reference intervals are generally given as $\bar{x} \pm 2 S_{\mathrm{T}}$. In this study the contribution of both biological (age, sex, hospitalisation) and analytical factors to the overall standard deviation is considered (tab. 1).

Intra-individual variations of laboratory values depend on several factors which have to. be considered in long term studies (longitudinal assessment). Some of these can be standardised, e.g. time of venipuncture, posture of the patient, choice between venous or capillary blood for analysis, fasting or non-fasting states of the patient, etc. More or less constantly or slowly changing factors are age, pregnancy, overweight, seasonal influences, etc., whilst others such as sex, menopause, etc., can be regarded as constant. Of utmost importance in the clinical evaluation of laboratory data are significant changes in consecutive values observed in the same individual (longitudinal assessment).

Twenty one routine clinical chemical laboratory parameters in a large population have been studied in order to determine to what extent the result of an analysis must be different from a preceding result to indicate a significant change. This minimal required difference is called the critical difference $d_{k}(1,2)$.

For the present investigation $d_{k}$ has been calculated from literature data and has been compared to the actual differences found between classified data in this study. In this way an attempt was made to confirm the clinical relevance of these differences, i.e. the influence of factors such as age, sex, hospitalisation, etc., on laboratory parameters.
Tab. 1. Symbols used in this study acc. to $\operatorname{Stamm}(1,2)$.

$$
\begin{aligned}
& S_{\mathrm{T}}^{2}=\text { variance in reference values } \\
& S_{\mathrm{T}}^{2}=S_{\mathrm{B}}^{2}+S_{\mathrm{A}}^{2}+S_{\text {other }}^{2} \rightarrow S_{\mathrm{T}}^{2}=S_{\mathrm{P}}^{2}+S_{\mathrm{I}}^{2}+S_{\mathrm{A}}^{2}+S_{\text {other }}^{2} \\
& S_{T^{\prime \prime}}^{2}=\text { total intra-individual variance } \underset{i}{\text { when }} S_{\mathrm{I}}^{2}=0 \\
& \mathrm{~S}_{\mathrm{T}^{\prime \prime}}^{2}=\mathrm{S}_{\mathrm{P}}^{2}+\mathrm{S}_{\mathrm{A}}^{2}+\mathrm{S}_{\text {other }}^{2} \\
& \mathrm{~S}_{\mathrm{B}}^{2}=\text { biological variance } \\
& S_{\mathrm{B}}^{2}=S_{\mathrm{P}}^{2}+S_{1}^{2} \mid S_{\mathrm{P}}^{2}=\text { intra-individual variance } \\
& S_{\mathrm{I}}^{2}=\text { inter-individual variance } \\
& S_{A}^{2}=\text { analytical variance } \\
& S_{A}^{2}=S_{S}^{2}+S_{L}^{2} i \quad S_{S}^{2}=\text { variance in the run } \\
& S_{L}^{2}=\text { long-term variance } \\
& S_{\text {other }}^{2}=\text { other variance, e.g. specimen collection }
\end{aligned}
$$

$d_{k}=$ critical difference

$$
d_{k}=2 \sqrt{2\left(S_{P}^{2}+S_{A}^{2}\right)}
$$

\section{Materials and Methods}

Subjects

The influence of sex, age and hospitalisation was studied by investigating laboratory data retrospectively from a population of 12000 patients. In order to eliminate the possible influence of disease all data from an individual were rejected if one of the data was outside the reference values. Different sub-populations were used for the study of the influence of hospitalisation, sex or age.

Although these procedures do not absolutely exclude all unhealthy patients, the influence of disease can be considered as neglegible. The influence of hospitalisation was studied by dividing the subjects into hospitalised and out-patient groups.

\section{Samples}

Blood samples were taken between 7.30 a.m. and 9.00 a.m. and reached the laboratory within one hour.

The clinical patients had been fasting for twelve hours before the blood was taken; no limitations on diet were prescribed for outpatients.

\section{Analytical procedures}

There was a high degree of conformity in analytical procedures between the different participating laboratories, which used identical control sera, standards and methods. Moreover, the data from a hospital (where continuous flow analysis, Technicon, SMAC, was used) in a different area were compared with the data from the hospitals in the study area.

\section{Analytical precision}

The analyses concerned are listed in table 2 together with the coefficients of variation. The calculated critical differences are also given in table 2 .

As expected, the analytical variation coefficient is larger in the data group obtained by continuous flow analysis. For every analysis, however, the relevant variation coefficient was used in the calculation of the critical difference $d_{k}$. 
Tab. 2. Laboratory parameters with coefficient of variation ( $C V \%)$ and critical differences $\left(d_{k}\right)$.

Coefficient of variation and critical differences were calculated from data within the transverse reference interval.

\begin{tabular}{|c|c|c|c|c|c|c|c|}
\hline & \multirow[t]{3}{*}{$C V_{p}(\%)$} & \multicolumn{3}{|c|}{$\mathrm{CV}_{\mathrm{A}}(\%)$} & \multicolumn{3}{|c|}{$d_{k}$} \\
\hline & & \multirow{2}{*}{$\begin{array}{l}\text { SMAC } \\
\text { One hospital }\end{array}$} & \multicolumn{2}{|c|}{ Other methods } & \multirow{2}{*}{$\begin{array}{l}\text { SMAC } \\
\text { One hospital }\end{array}$} & \multicolumn{2}{|c|}{ Other methods } \\
\hline & & & $\begin{array}{l}\text { One } \\
\text { hospital }\end{array}$ & Aréa & & $\begin{array}{l}\text { One } \\
\text { hospital }\end{array}$ & Area \\
\hline \multicolumn{8}{|l|}{ Enzymes } \\
\hline $\begin{array}{l}\text { Creatine kinase } \\
\text { Alanine aminotransferase } \\
\text { Aspartate aminotransferase } \\
\text { Lactate dehydrogenase } \\
\gamma \text {-Glutamyltransferase } \\
\text { Alkaline phosphatase } \\
\alpha \text {-Amylase }\end{array}$ & $\begin{array}{r}71.6 \\
42.2 \\
18.4 \\
7.6 \\
34.7 \\
6.6 \\
-\end{array}$ & $\begin{array}{r}14.9 \\
21.4 \\
18.8 \\
7.4 \\
10.1 \\
5.9 \\
-\end{array}$ & $\begin{array}{l}2.9 \\
2.4 \\
2.8 \\
3.4 \\
2.9 \\
2.3 \\
3.8\end{array}$ & $\begin{array}{r}14.0 \\
6.5 \\
4.5 \\
5.5 \\
11.8 \\
7.3 \\
3.9\end{array}$ & $\begin{array}{r}207 \\
134 \\
74 \\
30 \\
102 \\
25 \\
-\end{array}$ & $\begin{array}{r}203 \\
120 \\
53 \\
24 \\
99 \\
20 \\
-\end{array}$ & $\begin{array}{r}206 \\
121 \\
54 \\
27 \\
104 \\
28 \\
-\end{array}$ \\
\hline \multicolumn{8}{|l|}{ Electrolytes } \\
\hline $\begin{array}{l}\text { Sodium } \\
\text { Potassium } \\
\text { Chloride } \\
\text { Calcium } \\
\text { Phosphate }\end{array}$ & $\begin{array}{l}0.8 \\
4.6 \\
1.8 \\
1.7 \\
7.4\end{array}$ & $\begin{array}{l}0.7 \\
2.3 \\
1.7 \\
2.1 \\
3.5\end{array}$ & $\begin{array}{l}0.8 \\
1.7 \\
1.4 \\
1.5 \\
2.9\end{array}$ & $\begin{array}{l}1.1 \\
2.3 \\
1.5 \\
2.6 \\
2.9\end{array}$ & $\begin{array}{l}3.0 \\
15 \\
7.0 \\
7.6 \\
23\end{array}$ & $\begin{array}{l}3.2 \\
14 \\
6.5 \\
6.4 \\
23\end{array}$ & $\begin{array}{c}3.9 \\
15 \\
6.6 \\
8.8 \\
23\end{array}$ \\
\hline \multicolumn{8}{|l|}{ Intermediary metabolites } \\
\hline $\begin{array}{l}\text { Bilirubin } \\
\text { Glucose } \\
\text { Cholesterol } \\
\text { Triglycerides } \\
\text { Total protein } \\
\text { Urea } \\
\text { Creatinine } \\
\text { Uric acid }\end{array}$ & $\begin{array}{r}24.5 \\
6.2 \\
5.6 \\
30.3 \\
2.7 \\
13.4 \\
4.0 \\
8.7\end{array}$ & $\begin{array}{r}13.9 \\
4.8 \\
2.4 \\
3.6 \\
2.2 \\
5.1 \\
5.8 \\
5.0\end{array}$ & $\begin{array}{l}2.7 \\
2.5 \\
3.0 \\
4.6 \\
1.6 \\
3.2 \\
3.1 \\
3.8\end{array}$ & $\begin{array}{r}3.4 \\
5.0 \\
6.2 \\
13.7 \\
2.1 \\
5.9 \\
5.5 \\
3.6\end{array}$ & $\begin{array}{l}80 \\
22 \\
17 \\
86 \\
10 \\
41 \\
20 \\
28\end{array}$ & $\begin{array}{l}70 \\
19 \\
18 \\
87 \\
8.9 \\
39 \\
14 \\
27\end{array}$ & $\begin{array}{c}70 \\
23 \\
24 \\
94 \\
9.7 \\
41 \\
19 \\
27\end{array}$ \\
\hline \multicolumn{8}{|l|}{ Iron status } \\
\hline Iron & 26.6 & 5.6 & 5.3 & 9.4 & 77 & 77 & 80 \\
\hline
\end{tabular}

\section{Statistics}

Data obtained from 12000 healthy persons were arranged in consecutive classes and for each class the means $(\bar{x})$, standard deviations $\left(\mathrm{S}_{\mathrm{T}}\right)$ and the coefficients of variation $(\mathrm{CV})$ were calculated. In order to determine the presence of absence of significant differences between means of two populations, the standard deviations of the difference between class means were calculated as follows:

$$
S E_{\text {difference }}=\sqrt{\frac{S_{T_{1}}^{2}}{n_{1}}+\frac{S_{T_{2}}^{2}}{n_{2}}}
$$

The difference between class means was considered to be significant $(p<0.05)$ when it exceeded $2 \cdot \operatorname{SE}_{\text {difference }}(3,4)$.

Significant differences are often found in large populations. With this method a significant difference e.g. between chloride content of serum in males vs. females was found ( $p<0.001$, table 4).

It is evident that this difference between values from males and females of $1 \mathrm{mmol} / \mathrm{h}$ had not hitherto been considered clinically relevant. Another procedure was therefore tried, which is suitable for use in daily clinical practice, i.e. the method presented by the group of Young $(5)$. and confirmed by $\operatorname{Stamm}(1,2)$. With the formula $d_{k}=2 \sqrt{2\left(S_{P}^{2}+S_{A}^{2}\right)}$ the minimal value of the significant difference between two consecutive determinations of a same constituent in the same individual was calculated, and designated by Stamm as the "critical difference", $d_{k}$.
Many investigators (5-11) determined values for the intra-individual variance $S_{\mathrm{p}}^{2}$. Means of these data from the literature (table 3, last column) were used in the calculation of our results.

Values for $S_{A}$ were obtained from daily quality control analyses. Values for $C V_{P}$ and $C V_{A}$ and the critical differences are given in table 2.

As stated before we consider the difference between two values significant if its value exceeds the critical difference $d_{k}$.

\section{Results and Discussion}

As stated in the introduction, external influences on the clinical relevance of changing laboratory data were studied. In this introductory study the transverse reference values were assessed in different groups distinguished by age, sex and hospitalisation. and differences between group means were determined (tab. 4-7).

From a number of literature data (tab. 3) the so called critical differences, as used in the longitudinal assessment of patient laboratory data, were calculated and compared with the differences between the class means found in this study. 
Tab. 3. Published intra-individual variation (coefficient of variation $C V_{P}$ ) data. $C V_{P}$ values and literature references are given with the calculated $\overline{C V}$.

\begin{tabular}{|c|c|c|c|c|c|c|c|c|}
\hline Litcrature references & (5) & (6) & (7) & (8) & (9) & (10) & (11) & $\overline{C V}_{\mathbf{P}}$ \\
\hline \multicolumn{9}{|l|}{ Enzymes } \\
\hline Creatine kinase & 82.76 & - & - & - & - & 60.3 & - & 71.6 \\
\hline Alanine aminotransferase & 57.89 & - & - & 26.4 & - & - & - & 42.2 \\
\hline Aspartate aminotransferase & 14.79 & - & 15.1 & 24.2 & - & 19.3 & - & 18.4 \\
\hline Lactate dehydrogenase & 6.19 & 9.0 & 7.3 & - & - & 8.0 & - & 7.6 \\
\hline$\gamma$-Glutamyltransferase & - & - & - & - & - & 34.7 & - & 34.7 \\
\hline Alkaline phosphatase & 6.33 & - & 5.8 & 4.8 & 6.4 & 8.5 & 7.9 & 6.6 \\
\hline$\alpha$-Amylase & - & - & - & - & - & - & - & - \\
\hline \multicolumn{9}{|l|}{ Electrolytes } \\
\hline Sodium & 0.93 & - & 1.4 & 0.7 & 0.5 & - & 0.5 & 0.8 \\
\hline Potassium & 4.43 & 5.0 & 4.6 & 4.3 & 6.2 & - & 3.2 & 4.6 \\
\hline Chloride & 1.52 & 1.4 & 2.1 & 2.1 & - & - & - & 1.8 \\
\hline Calcium & 1.93 & 1.7 & 1.6 & 1.7 & 1.6 & 2.1 & 1.1 & 1.7 \\
\hline Phosphate & 7.40 & 7.5 & 9.6 & 5.8 & 6.8 & 8.2 & 6.2 & 7.4 \\
\hline \multicolumn{9}{|l|}{ Intermediary metabolites } \\
\hline Bilirubin & 25.59 & - & - & 22.0 & 26.0 & - & - & 24.5 \\
\hline Glucose & - & 5.6 & 6.5 & - & - & 6.5 & - & 6.2 \\
\hline Cholesterol & 4.39 & 6.4 & 4.2 & 5.3 & - & 7.9 & - & 5.6 \\
\hline Triglycerides & 33.33 & - & - & - & - & 27.3 & - & 30.3 \\
\hline Total protein & 2.51 & 2.8 & 2.3 & 2.9 & 3.0 & 3.3 & 2.0 & 2.7 \\
\hline Urea & 14.29 & 11.9 & 13.6 & 12.3 & 11.1 & 16.4 & 14.2 & 13.4 \\
\hline Creatinine & 3.83 & - & 4.4 & 4.3 & - & 3.1 & 4.2 & 4.0 \\
\hline Uric acid & 8.98 & 10.1 & 8.5 & 7.3 & - & 8.8 & - & 8.7 \\
\hline \multicolumn{9}{|l|}{ Iron status } \\
\hline Iron & - & - & - & 26.6 & - & - & - & 26.6 \\
\hline
\end{tabular}

\section{Influence of age}

In table 4 data obtained for different age classes are given. Only in four cases did the difference between consecutive classes exceed $d_{k}$, i.e. for alkaline phosphatase, lactate dehydrogenase, potassium and phosphate in serum. For these consituents the age class 1-9 years invariably produced higher values than other age classes. A gradual increase with age was noted for glucose, urea, creatinine, $\alpha$-amylase, cholesterol and uric acid. Values for glucose, creatinine, protein and uric acid content in the age class 1-9 years were significantly lower than in all classes over 20 years of age. The same was true for urea, $\alpha$ amylase, bilirubin, cholesterol, protein, and uric acid in the 1-9 years class as compared to all other classes.

Small variations were noted for several consecutive class means of $\gamma$-glutamyltransferase, alanine aminotransferase, aspartate aminotransferase, creatine kinase and serum iron concentration.

The constancy of sodium, chloride and calcium concentrations was striking. This has also been reported by Cotlove et al. (12) who suggested that it was due to endocrine regulation mechanisms.

The decreased levels of urea, creatinine, bilirubin and uric acid in the 30-39 years class must be noted as well as the low values for $\alpha$-amylase activity in the 60-69 years class, and the decrease of creatine kinase activity after 69 years of age.

On account of the existing differences in blood creatinine levels between men and women, separate age classes for both sexes are given (tab. 5). From 10 years of age and onwards significant differences between age classes were found in females. In males significant differences were also seen between the $1-9$ years and the $10-19$ years age groups, and perhaps between $70-79$ years and $>80$ years age groups.

Although a clinically relevant difference $(15 \mu \mathrm{mol} / \mathrm{l})$ existed overall between males vs. females this difference was not found in separate age classes. These findings are in good accordance with data from the literature $(10,13$ to 22$)$. 


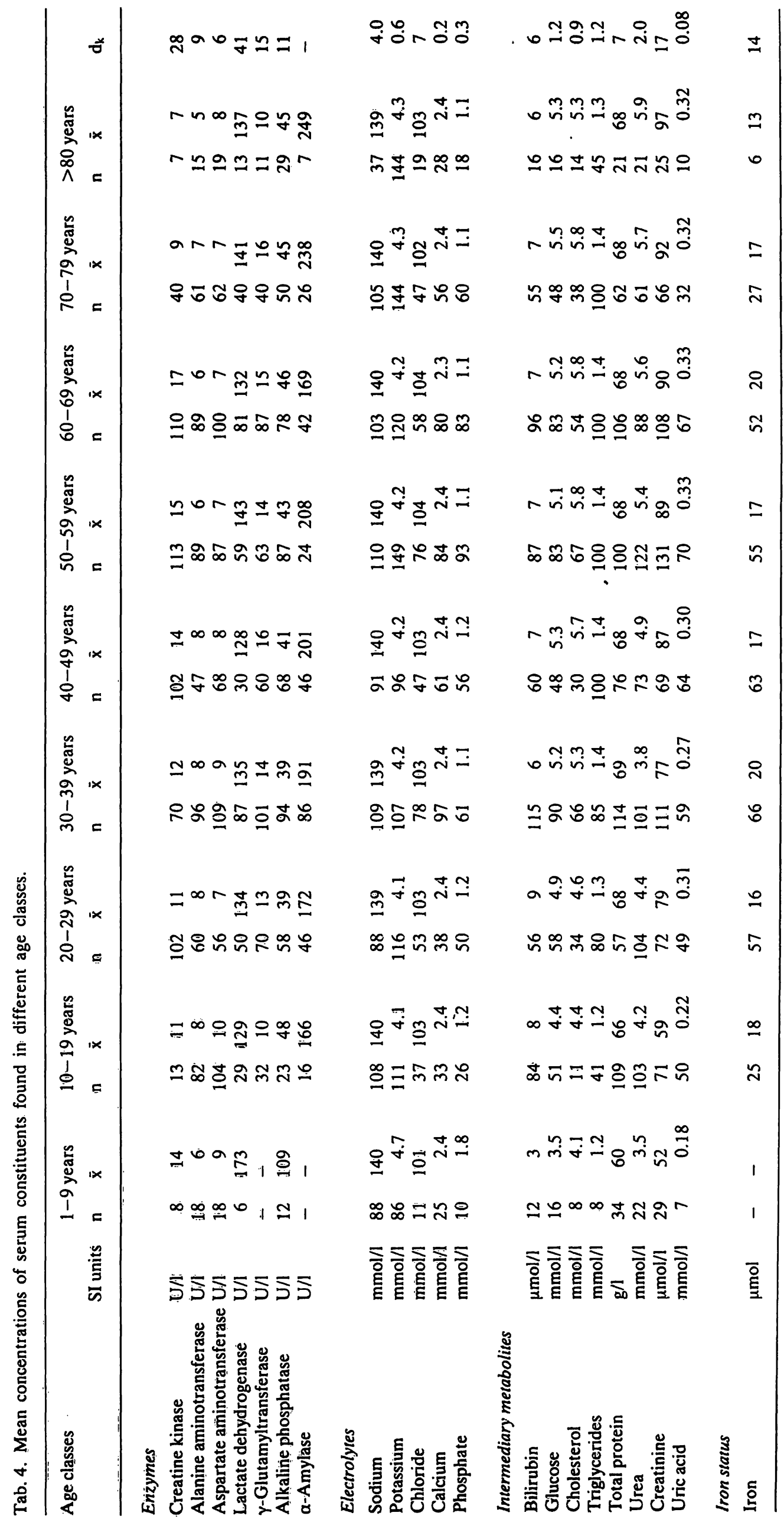


Tab. 5. Mean serum creatinine concentrations in different age classes for both sexes.

\begin{tabular}{llllllllllrrr}
\hline $\begin{array}{l}\text { Age class } \\
\text { (years) }\end{array}$ & & $1-9$ & $10-19$ & $20-29$ & $30-39$ & $40-49$ & $50-59$ & $60-69$ & $70-79$ & $>80$ & total \\
\hline Femalc & $\mathrm{n}$ & 18 & 42 & 41 & 81 & 30 & 96 & 74 & 39 & $: 1$ & 5 & 426 \\
& $\overline{\mathrm{x}}$ & 49 & 67 & 80 & 80 & 92 & 93 & 93 & 97 & 93 \\
Male & $\mathrm{n}$ & 11 & 24 & 35 & 40 & 33 & 30 & 39 & 26 & 19 & 257 \\
& $\overline{\mathrm{x}}$ & 42 & 55 & 78 & 76 & 83 & 86 & 85 & 89 & 93 & 78 \\
\hline
\end{tabular}

\section{Influence of sex}

In table 6 the influence of sex on the level of serum constituents is given. Although significant $(p<0.05)$ differences between mean values in sex classes were found for urea, creatinine, bilirubin, $\gamma$-glutamyltransferase, creatine kinase, cholesterol, uric acid, chloride, phosphate and iron, only in the case of creatinine did this difference approximate to the $d_{k}$ value $(17 \mu \mathrm{mol} / \mathrm{l})$

$$
\left|x_{m}-x_{f}\right|>2 \sqrt{2\left(S_{P}^{2}+S_{A}^{2}\right)}
$$

This difference therefore can be considered as clinically relevant which means that different reference ranges must be used. This is not the case for the other serum constituents where statistically significant, but clinically non-relevant differences between sex classes were found.

Here the intra-individual variance exceeds the variance between sex classes. Literature data $(10,13$, 19 to 22) for urea, creatinine, uric acid, cholesterol, creatine kinase, $\gamma$-glutamyltransferase and phosphate are in close agreement with our findings. Inconsistent values have been reported for $\alpha$-amylase, alkaline phosphatase, alanine aminotransferase, aspartate aminotransferase and calcium.

Tab. 6. Mean concentrations and group variations of serum constituent values for both sexes. Significant differences between sex groups $\left(S E_{\text {diff }}\right)$ and critical differences $\left(d_{k}\right)$ are given.

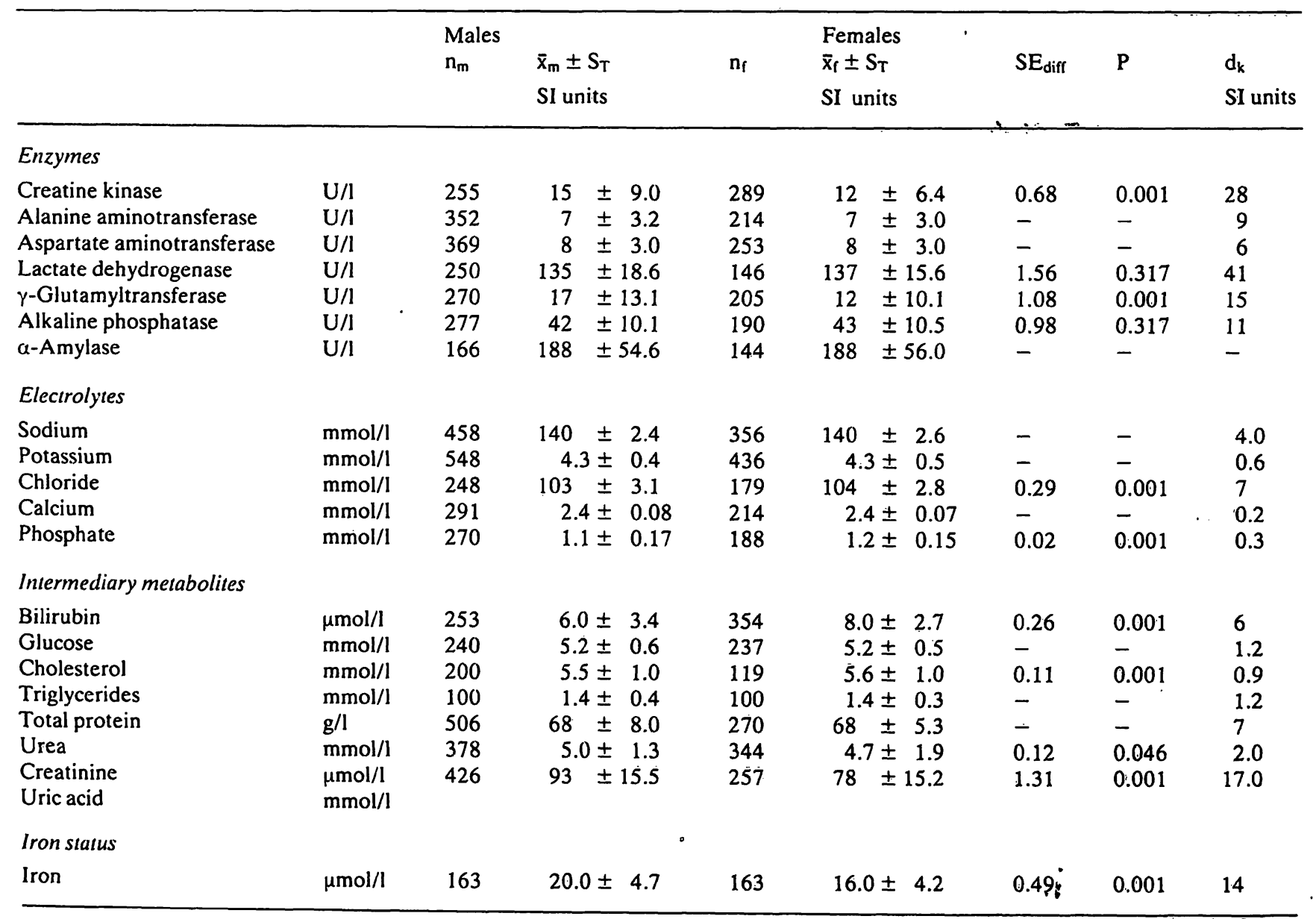




\section{Influence of hospitalisation}

Differences between laboratory data from hospitalised and out-patients can be expected on account of different behaviour (bed rest, diet, etc.).

A number of analyses in blood are generally performed before admission to hospital in order to reduce the duration of hospitalisation. This means that longitudinal assessment of laboratory values is complicated by the differences due to hospitalisation found in intra-individual follow up. The clinical relevance of this item has been studied (tab. 7).

It appeared that the differences were clinically relevant only for serum glucose and serum protein, i.e. they are equal to or in excess of the critical difference $\left(d_{k}\right)$.

The findings of Young (13), Schwarts (23) and Kreutzer \& Raymakers (20) concerning the influences of bed rest on potassium, calcium and phosphate levels were not confirmed.

\section{Other influences}

Many other factors possibly influence the levels of laboratory data. Reports have been published on seasonal influences $(12,13,20,24,25,26)$, diurnal rhythm $(13,20,23,27,28)$, smoking $(29,30)$, medication $(20,29$ to 33$)$, exercise $(20,23,29,34$ to 39$)$, pregnancy $(20,40,41,42)$, overweight $(20,23)$, blood transfusion $(13,29)$, intramuscular injection $(23,29)$, fasting $(13,20,23,29)$, and use of capillary or venous blood $(13,43,44)$.

\section{Clinical relevance}

For the general practitioner and the clinical specialist it is impossible to constantly take all these factors into account. However, especially in longitudinal studies, this is in principle important. It must be considered that elimination of some factors can be obtained by strict standardisation of blood sampling, e.g. always between 8.00-9.00 a.m., always from resting patients, always in fasting conditions, etc.

Tab. 7. Mean concentrations of serum constituents from hospitalised patients and out-patients. Critical differences ( $\left.d_{k}\right)$ are given for comparison.

\begin{tabular}{|c|c|c|c|c|c|c|}
\hline & & \multicolumn{2}{|c|}{ Hospitalised patients } & \multicolumn{2}{|c|}{ Out-patients } & \multirow[b]{2}{*}{$d_{k}$} \\
\hline & & $\mathrm{n}$ & $\overline{\mathbf{x}}$ & $\mathrm{n}$ & $\bar{x}$ & \\
\hline & SI units & & SI units & & SI units & SI units \\
\hline \multicolumn{7}{|l|}{ Enzymes } \\
\hline Creatine kinase & $\mathrm{U} / \mathrm{I}$ & 232 & 102 & 208 & 78 & 180 \\
\hline Alanine aminotransferase & $\mathrm{U} / 1$ & 229 & 23 & 226 & 19 & 25 \\
\hline Aspartate aminotransferase & $U / 1$ & 238 & 25 & 235 & 22 & 12 \\
\hline Lactate dehydrogenase & $U / 1$ & 230 & 369 & 228 & 324 & 74 \\
\hline$\gamma$-Glutamyltransferase & $U / 1$ & 220 & 24 & 230 & 21 & $2 \mathrm{i}$ \\
\hline Alkaline phosphatase & $U / 1$ & 231 & 98 & 231 & 92 & 13 \\
\hline$\alpha$-Amylase & $\mathrm{U} / 1$ & & & & & \\
\hline \multicolumn{7}{|l|}{ Electrolytes } \\
\hline Sodium & $\mathrm{mmol} / \mathrm{l}$ & 239 & 140 & 249 & 144 & 5 \\
\hline Potassium & $\mathrm{mmọl} / \mathrm{l}$ & 237 & 4.3 & 220 & 4.3 & 0.6 \\
\hline Chloride & $\mathrm{mmol} / \mathrm{l}$ & 236 & 100 & 179 & 102 & 7 \\
\hline Calcium & $\mathrm{mmol} / \mathrm{l}$ & 242 & 2.3 & 225 & 2.4 & 0.2 \\
\hline Phosphate & $\mathrm{mmol} / \mathrm{l}$ & 230 & 1.1 & 239 & 1.1 & 0.2 \\
\hline$\ddot{*}$ & & & & & & \\
\hline \multicolumn{7}{|l|}{ Intermediary metabolites } \\
\hline Bilịụbin & $\mu \mathrm{mol} / \mathrm{l}$ & 232 & 9.9 & 234 & 7.9 & 6.0 \\
\hline Glucose & $\mathrm{mmol} / \mathrm{l}$ & 234 & 7.4 & 227 & 5.2 & 0.9 \\
\hline Cholesterol & $\mathrm{mmol} / \mathrm{l}$ & 250 & 6.1 & 236 & 6.4 & 1.1 \\
\hline Triglycerides & $\mathrm{mmol} / \mathrm{l}$ & 230 & 1.4 & 234 & 1.6 & 1.2 \\
\hline Total protein & $\mathrm{g} / \mathrm{l}$ & 250 & 61 & 250 & 69 & 6 \\
\hline Urea & $\mathrm{mmol} / \mathrm{l}$ & 236 & 5.9 & 230 & 5.6 & 2.2 \\
\hline Creatinine & $\mu \mathrm{mol} / 1$ & 231 & 96 & 229 & 88 & 14 \\
\hline Uric acid & $\mathrm{mmol} / \mathrm{I}$ & 241 & 0.36 & 237 & 0.33 & 0.08 \\
\hline \multicolumn{7}{|l|}{ Iron status } \\
\hline Iron & $\mu \mathrm{mol} / \mathrm{l}$ & 174 & 8 & 231 & 14 & 11 \\
\hline
\end{tabular}


It is impossible to standardise other factors such as age, sex, seasonal influences, pregnancy, blood transfusion, etc. In order to improve the benefit of using laboratory data a scheme was developed by which the influence of a number of factors on 21 common laboratory data can be shown (tab. 8). We have differentiated between factors influencing laboratory data without clinical relevance and those which may be relevant for clinical decision making, i.e. those where the differences observed exceed the critical difference $\left(d_{k}\right)$ value.

The use of this scheme enables the practising clinician to take into account any possible alteration in circumstances since the previous blood sample was taken. In this procedure the patient is used as his own reference in a longitudinal follow up, such as in the course and development of disease, and in the treatment phase.

Tab. 8. Several influences on clinical chemical serum parameters. Legends: $\uparrow$ clinically significant increase; $\downarrow$ clinically significant decrease; + increased; - decreased; O no influence; $\$$ female; $\delta$ male. Seasons: 1 Spring; 2 Summer; 3 Autumn; 4 Winter.

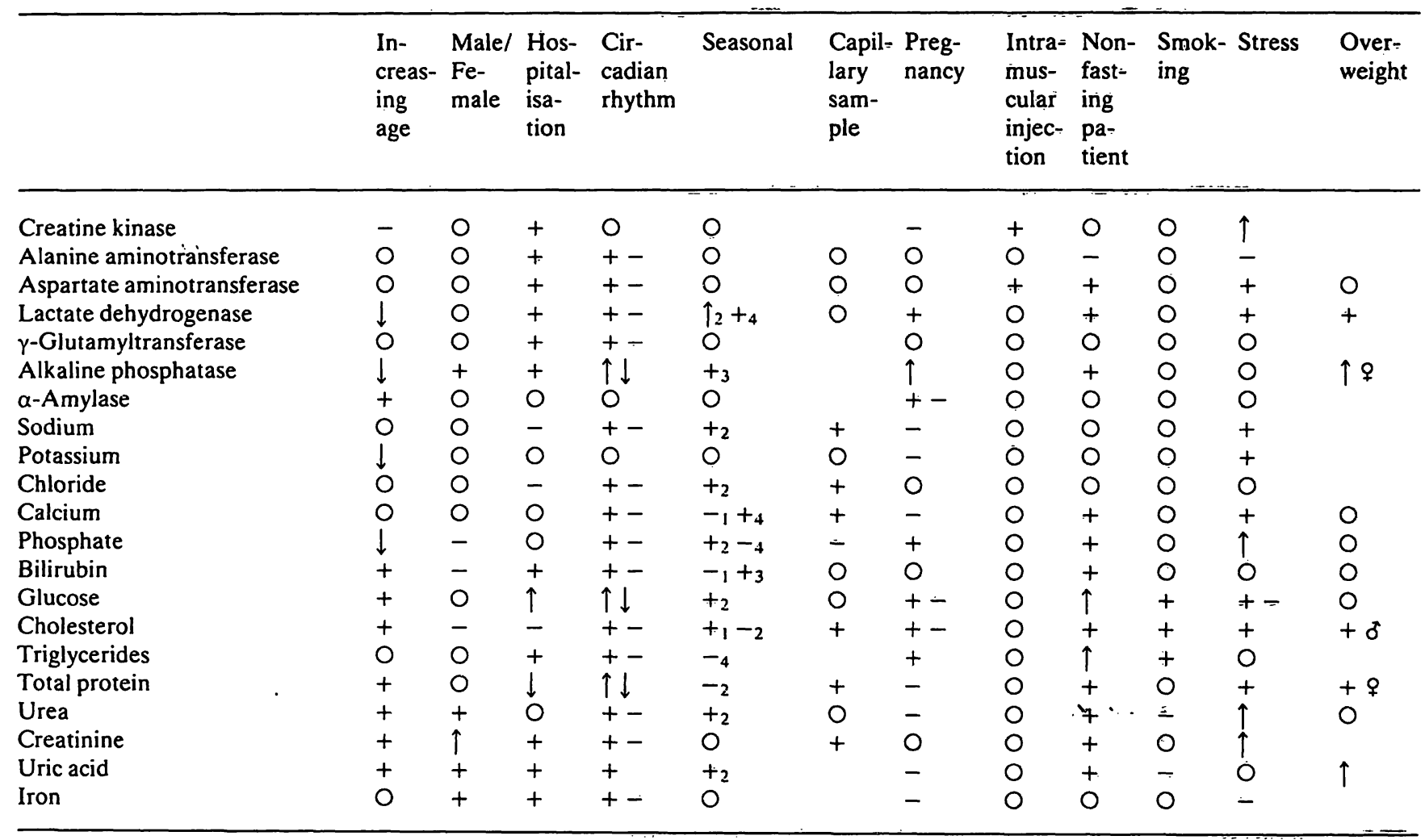

\section{References}

1. Stamm, D. (1981) In: Reference values in laboratory medicine. The current state of the art, pp. 109-126 (Gräsbeck, R. \& Alström, T., eds.). John Wiley \& Sons, Chichester.

2. Stamm, D. (1982) J. Clin. Chem. Clin. Biochem. 20,817= 824.

3. Swinscow, T. P. V. (1976) Brit. Med. J. 2, 33-34.

4. Swinscow, T. P. V. (1976) Brit. Med. J. 2, 94-95.

5. Steigterhem, A. C., Robertson, E. A. \& Young, D. S. (1978) Clin. Chem. 24, 212-222.

6. Harris, E. K., Kanofsky, P., Shakarji, C. \& Cotlove, E. V. (1970) Clin. Chem. 16, 1022-1027.

7. Young, D. S., Harris, E. K. \& Cotlove, E. V. (1971) Clin. Chem. 17, 403-410.

8. Winkel, P., Statland, B. E. \& Bokelund, H. (1974) Clin. Chem. 20, 1520-1527.

9. Pickup, Harris, E. K., Kearns, M. \& Brown, S. S. (1977) Clin Chem. 23, 842-850.

10. Williams, G. Z., Widdowson, G. M. \& Penton, J. (1978) Clin. Chem. 24, 313-320.
11. Winkel, P., Statland, B. E. \& Bokelund, H. (197̈5) Am. J. Clin. Pathol. 64, 433-447.

12. Cotlove, E., Harris, E. K. \& Williams, G. Z. (1970) Clin. Chem. 16, 1028-1032.

13. Young, D. S. (1980) In: Chemical diagnosis of disease, pp. 3-112 (Brown, S. S., Mitchell, F. L. \& Young, D. S., eds.): Elsevier/North-Holland Biomedical Prèss Amsterdam.

14. Wilding, P., Rollason, J. G. \& Robinson, D. (1972) Clin. Chim. Acta 41, 375-387.

15. Cheek, D. B. (1968) Human-growth, energy and intelligence, Lea \& Fibiger, Philadelphia.

16. Hodgson, P. A., Ellefson, R. D., Elveback, L. R., Harris, L. E., Nelson, R. A. \& Weidmann, W. H. (1976) Metabolism 25, 739-746.

17. Buckley, C. E. \& Dorsey, F. E. (1971) Ann. Interñ. Med. 75, 673-682.

18. Gairdner, D., Marks, J., Rosche, J. D. \& Brettel, R. A. (1958) Arch. Dis. Child. 33, 498.

19. Harm, K. (1981) Lab. Med. 5, '134-141. 
20. Kreutzer, H. H. \& Raymakers, J. A. (1982) In: Interpretatie van uitkomsten van laboratorium-onderzoek in de geneeskunde pp. 1-140. Bohn, Scheltema \& Holkema Utrecht/ Antwerpen.

21. Henzc, K. (1981) J. Clin. Chem. Clin. Biochem. 19, 10131019.

22. Witt, I. (1982) J. Clin. Chem. Clin. Biochem. 20, 235-242.

23. Schwartz, M. K. (1972) Adv. Clin. Chem. 16, 1-45.

24. Fuller, J. H., Grainger, S. L., Jarett, R. J. \& Keen, H. (1974) Clin. Chim. Acta 52, 305-310.

25. Fahlen, M., Oden, A., Bjorntorp, P. \& Tibblin, G. (1971) Clin. Sci. 41, 453-458.

26. Green, A. G. (1974) J. Clin. Pathol. 27, 923-941.

27. Simpson, H. W. (1976) Med. Biochem. 2, 115-158.

28. Wisser, H. (1981) J. Clin. Chem. Clin. Biochem. 19, 323337.

29. Young, D. S., Pestaner; L. C. \& Gibberman, V. (1975) Clin. Chem. 21, 1D-432D.

30. Sandberg, H., Roman, L., Zavednick, J. \& Kupers, N. (1973) J. Pharmacol. Exp. Ther. 184, 789-898.

31. Siest, G. (1980) Drugs effects on laboratory test results, Martinus Nyhoff, The Hague.

32. Sher, P. P. (1982) Drugs 24, 24-63.

33. Winkelman, J. W., Cannon, D. C., Pileggi, V. J. \& Reed, A. H. (1973) Clin. Chem. 19, 488-491.
34. Naveri, H., Rehunen, S., Kuoppasalmi, K., Tulikowa, I. \& Härkönen, M. (1978) Scand. J. Clin. Lab. Invest. 38, 329336.

35. Maehlum, S. \& Hermansen, L. (1978) Scand. J. Clin. Lab. Invest. 38, 557-560.

36. Maehlum, S., Hostmark, A. T. \& Hermansen, L. (1977) Scand. J. Clin. Lab. Invest. 37, 309-316.

37. Olssen, A. G., Eklund, B., Kayser, L. \& Carlson, L. A. (1975) Scand. J. Clin. Lab. Invest. 35, 231-236.

38. Refsum, H. E. \& Strömme, S. B. (1975) Scand. J. Clin. Lab. Invest. 35, 775-780.

39. Refsum, H. E., Tveit, B., Meen, H. D. \& Strömme, S. B. (1973) Scand. J. Clin. Lab. Invest. 32, 117-122.

40. Leckie, B., Brown, J. J. \& Lever, A. F. (1976) Lancet II, 748-749.

41. Lim, V. S., Katz, A. I. \& Lindheimer, M. D. (1976) Amer. J. Physiol. 231, 1764-1770.

42. Hytten, F. E. \& Lind, I. (1973) In: Diagnostic indices in pregnancy pp. 3210-0123, Ciba-Geigy, Basel.

43. Falch, D. K. (1981) Scand. J. Lab. Invest. 41, 59-65.

44. Kupke, I. R., Kather, B. \& Zeugner, S. (1981) Clin. Chim. Acta $112,177-185$.

45. Bezemer, P. D. (1981) In: Referentiewaarden, pp. 1-66, Thesis, Amsterdam.

46. Wulff, H. R. (1980) Princips van klinisch denken en handelen. Bohn, Scheltema \& Holkema, Utrecht.

47. Lommel, H. \& Weger, M. G. (1982) Lab. Med. 6, 14-21.

Dr. med. G. M. P. J. Costongs Department of Clinical Chemistry

"Ziekenhuis De Goddelijke Voorzienigheid"

Walramstraat 23

NL-6131 BK Sittard 
